\title{
Rekonstruksi konsep fakir dan miskin sebagai mustahik zakat
}

\author{
Dede Rodin \\ Fakultas Ekonomi dan Bisnis Islam UIN Walisongo Semarang \\ E-mail:dederodin@gmail.com
}

\begin{abstract}
Among asnaf are entitled to receive zakat is faqiir and miskin, but both groups are often interpreted overlap.This article aims to reconstruct the concept of faqir and miskin with perspective of the Qur'an. This is because that, in addition to the Qur'an is believed by Muslims as the main source of law, also the concept of faqir and miskin as well as 'illat that causes both as mustahik zakat will make the distribution of zakat in accordance with its objectives. The study of the verses of the Qur'an about the faqir and miskin, results the conclusions: First, faqiir is who are deterred from livelihoold as work reason or udhur. The work reason is due to religious activity or work shar'i as da'wah and jihad. While the udhur reason caused by kauni destiny like a disability, palsied, and old. Thus, 'illat for faqr groups derived from God's glory and the exam so that they get the respect, zakat and other compensation. The glory reason coming from the work shar'iyyah, while the test reason comes from udbur kauniyyah. While the miskin are literally means sakana; silent and not moving, that miskin terms describe the result of a weak state of a person because he chose sakana lifestyle (silent, static, not developing skills in his life). As a result he became poor and do not have anything whatsoever to fulfill their needs.
\end{abstract}

Di antara asnaf yang berhak menerima zakat adalah fakir dan miskin, tetapi kedua kelompok ini seringkali dimaknai tumpang tindih. Tulisan ini bertujuan untuk merekonstruksi konsep fakir dan miskin, khususnya dari perspektif al-Qur'an. Karena, di samping al-Qur'an diyakini oleh umat Islam sebagai sumber utama hukum, juga kejelasan konsep fakir dan miskin serta 'illat yang menyebabkan keduanya sebagai mustahik zakat akan membuat penyaluran zakat sesuai dengan tujuannya. Dari kajian ayat-ayat al-Qur'an tentang fakir dan miskin, dihasilkan temuan sebagai berikut: Pertama, fakir adalah mereka yang terhalang dari mencari nafkah karena sebab amal maupun udhur. Sebab amal adalah karena aktivitas keagamaan atau amal syar'i seperti dakwah dan jihad. Sedangkan sebab udhur dikarenakan takdir kauni seperti cacat, lumpuh dan tua. Jadi, 'illat bagi kelompok fakir berasal dari kemuliaan dan ujian Allah sehingga mereka mendapatkan penghormatan dan kompensasi zakat dan yang lainnya. Sebab kemuliaan datang dari amalan syar'iyyah, sedangkan sebab ujian datang dari udhur kauniyyah. Sedangkan miskin yang secara bahasa berasal dari kata sakana bermakna "diam dan tidak bergerak". Ini mengisyaratkan bahwa istilah miskin menggambarkan akibat dari keadaan diri seseorang yang lemah karena ia memilih 
ljtihad, Jurnal Wacana Hukum Islam dan Kemanusiaan, Volume 15, No. 1, Juni 2015: 137-158

pola hidup sakana (diam, statis, tidak mengembangkan keterampilan dalam hidupnya). Akibatnya ia menjadi miskin dan tidak memiliki sesuatu apa pun untuk memenuhi kebutuhan hidupnya.

Keywords: Faqiir; Miskin; Mustahiq; 'Tllat

\section{Pendahuluan}

Salah satu aspek penting dalam pelaksanaan ibadah zakat, baik pada tataran konsep maupun praktik, adalah konsep mustahik zakat. Para ulama ekonomi dan sosial menjelaskan bahwa persoalan terpenting dalam zakat bukan sekedar menarik dan mengumpulkan zakat, tetapi kemana zakat ini akan didistribusikan setelah terkumpul. Ini sebabnya mengapa al-Quran memberikan perhatian yang sangat besar terhadap masalah ini dan tidak membiarkan masalah ini secara global (al-Qaradawy, 1973:543).

Mustahik zakat adalah kelompok (așnaf) yang berhak untuk menerima zakat. Mereka adalah sasaran redistribusi yang sudah ditetapkan syariat, sebagaimana disebutkan dalam QS. al-Tawbah [9]:60:

"Sesungguhnya zakat-zakat itu, hanyalah untuk fukara, masakin, amilin (para petugas zakat), muallaf (orang yang dibujuk) hatinya, riqab (untuk memerdekakan budak), gharimin (orang-orang yang berhutang), sabilillah dan ibnu sabil, sebagai sesuatu ketetapan yang diwajibkan Allah; dan Allah Maha Mengetahui lagi Maha Bijaksana” (QS. al-Tawbah [9]:60).

Dalam ayat di atas, dijelaskan delapan kelompok (așnaf) yang berhak menerima zakat, yakni (1) fuqarā' (jamak dari faqiir), (2) masākin (jamak dari miskīin), (3) 'amilīn (jamak dari 'ámi), (4) mu'allaf, (5) riqāb, (6) gärimīn (jamak dari gärim), (7) sabīillāh, dan (8) ibnu sabīil. Pendistribusian zakat kepada mereka, selain merupakan persoalan keadilan, juga merupakan penunaian amanah dan wasiat dari Allah Swt agar ditunaikan sesuai dengan perintah-Nya.

Penyebutan nama-nama ini secara sengaja menunjukkan perbedaan secara konseptual masing-masing kelompok tersebut. Perbedaan tersebut adalah perbedaan alasan dan motif ('illat). Meskipun seorang mustahik bisa termasuk ke dalam lebih dari satu kelompok, tetapi alasan ('illat) pemberian zakat kepada mereka harus jelas dan definitif. Maksudnya, bisa saja seseorang termasuk kelompok fakir, garim dan muallaf sekaligus. Tapi, ketika zakat diserahkan kepadanya harus jelas alasan pemberiannya, apakah zakat diberikan kepadanya karena fakir, 
garim atau muallaf. Dengan demikian, dapat ditegaskan konsepsi masing-masing kelompok tersebut berbeda meskipun dimungkinkan terjadinya irisan.

Posisi aṣnaf fakir dan miskin sebagai aṣnaf zakat semestinya menjadi penting untuk diketahui dan diprioritaskan. Al-Quran menyebutnya sebagai kelompok pertama dan kedua yang berhak menerima zakat. Ini menunjukkan bahwa tujuan utama dari zakat adalah menyelesaikan problem kemiskinan (al-Qardawy, 1973:543). Bahkan dalam konteks zakat fitrah, fakir dan miskin itulah yang secara tegas disebutkan Nabi Saw dalam hadisnya:

Ibnu Abbas berkata, "Rasulullah Saw mewajibkan zakat fitrah untuk mensucikan orang yang berpuasa dari kesia-siaan dan kejahatan serta memberi makan orang miskin (mu'matan li al-masäkin). Barangsiapa yang menunaikannya sebelum shalat (Idul Fitri) maka itu adalah zakat yang diterima, dan barangsiapa yang menunaikannya setelah shalat Idul Fitri maka itu adalah sedekah" (Sunan Abi Dāwud, hadis no. 1371)

Dari Ibnu Abbas ra bahwa Nabi Saw mengutus Muaz ra ke Yaman. Beliau bersabda, "Ajak mereka agar bersaksi bahwa tidak ada tuhan kecuali Allah dan bahwa aku adalah utusan Allah. Jika mereka mengakui hal itu, maka ajarkan kepada mereka bahwa Allah telah mewajibkan atas mereka shalat 5 (lima) waktu sehari semalam. Jika mereka melakukan hal itu, maka ajarkan kepada mereka bahwa Allah telah mewajibkan atas mereka sedekah (zakat) pada harta mereka yang diambil dari orang-orang kaya mereka dan diberikan kepada fukara mereka" (Ṣaḥh al-Bukhāry, hadis no. 1308)

Selama ini, permasalahan yang muncul dalam penyaluran zakat kepada fakir dan miskin adalah ketidakjelasan kriteria dan batasan masing-masing. Fakir masih sering tumpang tindih maknanya dengan miskin, bahkan dengan așnăf yang lain. Terkadang, fakir disebut sebagai bagian dari golongan miskin atau sebaliknya. Sebagai misal, al-Sayyid Sabiq menulis:

"Tidak ada perbedaan yang berarti antara fakir dan miskin dari segi kebutuhan, kekurangan dan hak mendapat zakat. Penggabungan orang fakir dan miskin dengan menggunakan ataf (kata sambung) yang cenderung membedakan antara keduanya di dalam ayat di atas tidak bertentangan dengan apa yang saya sebutkan. Hal itu karena orang-orang miskin dimana mereka merupakan bagian dari orang-orang fakir- memiliki sifat yang khusus. Sifat khusus ini sudah cukup untuk menjadi pembeda di antara keduanya" (Sabiq, t.th:383).

Pada banyak buku dan literatur tentang zakat, kelompok fakir dan miskin ditulis dalam satu pembahasan. Sebagai contoh pada buku Fiqh al-Zakāh karya Yusuf al-Qardawy, Fiqh al-Sunnah karya Sayyid Sabiq, Fiqh Zakat Indonesia yang disusun oleh Didin Hafidhuddin, dkk, dan karya-karya lain. Demikian juga dalam Undang-Undang Republik Indonesia No.13 
ljtihad, Jurnal Wacana Hukum Islam dan Kemanusiaan, Volume 15, №. 1, Juni 2015: 137-158

Tahun 2011 tentang penanganan fakir miskin, istilah fakir dan miskin dianggap sama. Dalam tataran praktik penyaluran pun, așäff fakir sering digabungkan dengan miskin. Ini, misalnya, dapat dilihat dalam laporan penyaluran zakat yang diterbitkan berbagai lembaga resmi.

Padahal, penggabungan aṣnff fakir dan miskin dalam satu pembahasan dan satu anggaran penyaluran, menandakan ketidakmampuan membedakan karakteristik kedudukan masingmasing as \}näf tersebut. Ini berarti menafikan hikmah penyebutan nama fuqarä, dan masäkīn dalam al-Quran, sehingga seolah-olah penyebutan tersebut sia-sia. Apalagi, jika kita berpegang pada pendapat sebagian ahli bahasa bahwa tidak ada sinonimitas (taräduf) dalam al-Qur'an.

Ketidakjelasan konsep kedua istilah itu pula yang menyebabkan para ulama berselisih pendapat manakah yang kondisinya lebih parah antara fakir dan miskin. Ulama Shafi'iyyah dan Hanabilah berpendapat bahwa fakir itu lebih parah dari miskin. Alasan mereka karena dalam QS. al-Tawbah [9]:60 tentang zakat Allah menyebut fakir dahulu setelah itu menyebut miskin. Ulama lainnya berpendapat miskin lebih parah dari fakir. Adapun batasan dikatakan fakir menurut ulama Shafi'iyyah dan Malikiyyah adalah orang yang tidak punya harta dan usaha yang dapat memenuhi kebutuhannya (Wizārah al-Awqāf: 1427:23/312-313).

Dengan demikian, rekonstruksi konsep fakir dan miskin sebagai mustahik zakat menjadi penting untuk dilakukan, terutama dari perspektif al-Qur'an sebagai sumber hukum pertama. Kejelasan konsep dan definisi fakir dan miskin serta 'illat yang menyebabkan kedua kelompok ini sebagai mustahik zakat akan membuat penyaluran zakat sesuai dengan amanah dan wasiat Allah sebagaimana dinyatakan dalam al-Qur'an. Yang menjadi fokus permasalahan dalam tulisan ini setidaknya ada dua hal. Pertama, bagaimana konsep al-Qur'an tentang fakir dan miskin, dan kedua, apa yang menjadi 'illat fakir dan miskin sebagai mustahik zakat yang membedakannya dari aṣnăf yang lain.

\section{Makna term fakir dalam al-Qur'an}

Dalam Kamus Bahasa Indonesia, fakir diartikan sebagai (1) orang yang dengan sengaja membuat dirinya menderita kekurangan (untuk mencapai kesempurnaan batin), (2) orang;orang yang sangat kekurangan; kefakiran; kemiskinan (Pusat Bahasa, 2008:401).

Kata fakir, berasal dari bahasa Arab, faqiir, yang akar katanya terdiri dari huruf fa-qaf-ra, yang maknanya menunjukkan adanya celah pada sesuatu. Kata faqār (jamak dari faqarah) 
berarti tulang belakang) pada punggung. Kata itu menunjuk celah-celah dan sendi-sendi yang ada di antara tulang-tulang. Dari kata ini kemudian terbentuk kata fagir (fakir) yang menunjukkan seseorang yang seolah-olah patah seperti tulang belakangnya karena kehinaan dan kemelaratannya, atau beban yang dipikulnya sedemikian berat sehingga "mematahkan" tulang punggungnya.

Dalam kitab al-Mu'jam al-Wasit, di antara pengertian kata faqìr adalah: (1) Faqara fagran (فقر فقر) , bermakna dia mengeluhkan tulang punggungnya, karena patah atau karena sakit, (2) Faqara al-syay'a (نقر الشيء) bermakna dia ia amat fakir, (3) Iftaqara (افتقر) bermakna dia menjadi fakir dan membutuhkan sesuatu, (4) Tafäara (تفاقر) bermakna ia menampakkan

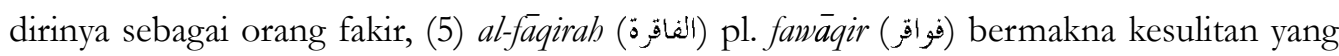
besar, (7) al-faqr (الفقر) bermakna kesulitan/kesusahan dan kebutuhan, (8) al-fagir bermakna orang yang patah tulang punggungnya (Majma' al-Lugah: t.th.: 697).

Sedangkan menurut al-Ragib al-Isfahni, sebagaimana dikutip oleh Asep Usman Ismail, istilah faqì memiliki empat pengertian (Ismail, 2012:41-42).

Pertama, orang yang membutuhkan Allah. Kebutuhan ini merupakan kebutuhan eksistensial yang berkenaan dengan eksistensi manusia, yakni bahwa setiap manusia secara universal membutuhkan Allah Swt, sebagaimana dinyatakan di dalam ayat berikut ini:

"Hai manusia, kalian yang membutuhkan Allah; dan Allah Dia-lah Yang Maha Kaya (tidak membutuhkan sesuatu) lagi Maha Terpuji” (QS. Fātị [35]:15).

"Maka Musa memberi minum ternak itu untuk (menolong) keduanya, kemudian dia kembali ke tempat yang teduh lalu berdoa: Ya Tuhanku sesungguhnya, aku sangat memerlukan sesuatu kebaikan yang Engkau turunkan kepadaku" (QS. al-Qacac [28]:24).

Kedua, membutuhkan, dalam pengertian bahwa setiap orang membutuhkan makanan dan minuman serta kebutuhan fisik-biologis lainnya untuk menjaga kelangsungan hidupnya.

Ketiga, tidak memiliki, tidak mengakses, dan tidak mendapatkan sembilan bahan pokok (sembako) untuk memenuhi kebutuhan hidup setiap hari sehingga ia menjadi membutuhkan pertolongan dan bantuan dari yang memiliki kemampuan.

Keempat, berarti fagr al-nafs, yakni jiwa yang tidak memiliki, tidak mengakses, dan tidak mendapatkan siraman ruhani untuk pengayaan batin. 
ljtihad, Jurnal Wacana Hukum Islam dan Kemanusiaan, Volume 15, No. 1, Juni 2015: 137-158

Berdasarkan makna-makna kebahasaan (etimologi) tersebut, dapat disimpulkan bahwa fakir mengandung makna penanggung jawab (tulang punggung) yang tidak mampu bekerja karena cacat dan tidak memiliki akses, sementara ia sangat membutuhkan dan kesulitan.

Sedangkan dalam al-Qur'an, kata faqïr dan berbagai derivasinya disebut sebanyak 14 kali, dengan perincian sebagai berikut. Pertama, kata al-fagr disebut dalam QS. al-Baqarah [2]:268). Kedua, kata faqīr disebut dalam QS. Ali Imrān [3]:181; al-Qaṣaṣ [28]:24; faqïran dalam QS. al-Nisa' [4]:6 dan 135; al-faqìr dalam QS. al-Hajj [22]:28). Ketiga, kata fuqarä, disebut dalam QS. al-Nūr [24]:32; Fạtir [35]:15 dan al-fuqarä' dalam QS. al-Baqarah [2]:271 dan 273; al-Tawbah [9]:60; Fațir [35]:15; Muḥammad [47]:38; al-Hasyr [59]:8. Keempat, kata fäqirah disebut dalam QS. al-Qiyāmah [75]:25.

Dari sisi tempat turunnya, QS. al-Baqarah [2]:271 dan 273, al-Tawbah [9]:60, al-Hajj [22]:28, dan al-Hasyr [59]:8 termasuk madaniyyah. Term fakir dalam ayat-ayat tersebut berkedudukan sebagai pihak yang menerima, yaitu penerima sedekah (QS. al-Baqarah [2]:271), penerima infak (QS. al-Baqarah [2]:273), penerima zakat (QS. al-Tawbah [9]:60), penerima daging kurban (QS. al-Hajj [22]:28), dan penerima fa’i (QS. al-Hasyr [59]:8).

Dari ayat-ayat di atas, ayat-ayat yang menyebutkan orang fakir yang harus dibantu dan dibebaskan dari kefakirannya adalah QS. al-Baqarah [2]:271 dan 273, al-Hasyr [59]:8; alTawbah [9]:60 dan al-Hajj [22]:28, sedangkan kata faqï dan fuqarä' dalam QS. Ali Imrān [3]:181, al-Nisā' [4]:6 dan 135, al-Nür [24]:32, al-Qaṣaṣ [28]:24, dan Muhammad [47]:38 tidak dalam pengertian fakir dalam konteks sosial yang harus dibantu sisi ekonominya. Sementara kata fáqirah dalam QS. al-Qiyamah [75]:25 berarti "malapetaka yang amat dahsyat". Ayat itu berbicara tentang keadaan orang kafir pada hari akhir, sehingga secara kontekstual tidak ada hubungannya dengan istilah fakir secara ekonomi. Namun dari aspek kebahasaan, kata itu mengingatkan bahwa kefakiran sejatinya merupakan sebuah malapetaka yang harus ditanggulangi, apa pun penyebabnya.

Dari sisi kandungan kita dapat melihat ayat-ayat tersebut sebagai berikut:

QS. al-Baqarah [2]:271:

"Jika kalian menampakkan sedekah-sedekah(mu), maka itu adalah baik sekali. Dan jika kalian menyembunyikannya dan kalian memberikannya kepada orang-orang fakir, maka menyembunyikan itu lebih baik bagimu. Dan Allah akan menghapuskan dari kalian 
sebagian kesalahan-kesalahanmu; dan Allah mengetahui apa yang kalian kerjakan.” (QS. al-Baqarah [2]:271).

Ayat tersebut berbicara tentang dua cara pemberian sedekah, bisa terang-terangan atau sembunyi-sembunyi. Kedua cara itu dibenarkan al-Qur'an, mana yang lebih baik tergantung pada kondisinya. Sedekah yang sunnah sebaiknya diberikan secara sembunyi-sembunyi supaya terhindar dari sifat riya. Sementara untuk sedekah wajib, semisal zakat, maka pemberiannya secara terangan-terangan lebih baik sebagai bentuk pelaksanaan atas ajaran agama.

QS. Al-Baqarah [2]:273:

"(Berinfaklah) kepada orang-orang fakir yang terikat (oleh jihad) di jalan Allah; mereka tidak dapat (berusaha) di muka bumi; orang yang tidak tahu menyangka mereka orang kaya karena memelihara diri dari minta-minta. Kamu kenal mereka dengan melihat sifatsifatnya, mereka tidak meminta kepada orang secara mendesak. Dan apa saja harta yang baik yang kalian nafkahkan (di jalan Allah), maka sesungguhnya Allah Maha Mengetahui." (QS. al-Baqarah [2]:273).

Menurut Ahmad Mustafa al-Maragy, ayat ini turun pada abl suffah yang terdiri dari 400 orang kaum muhajirin yang miskin. Mereka mengonsentrasikan dirinya untuk menghapal al-Qur'an dan berjihad di jalan Allah. Mayoritas mereka tidak memiliki tempat tinggal. Karena itu, mereka tinggal di suffah, sebuah tempat yang beratap di masjid Nabawi. Mereka berhijrah untuk mempertahankan agamanya dan meninggalkan harta mereka sehingga mereka menjadi orang-orang fakir (al-Maragy, 1946:3/51).

Ayat ini berbicara bahwa infak -yang disebutkan pada ayat sebelumnya (QS. al-Baqarah [2]:272) - diberikan kepada orang-orang fakir, khususnya dari kalangan muhajir yang meninggalkan harta dan keluarga mereka di Makkah. Mereka kemudian mewakafkan dirinya untuk berjihad di jalan Allah sehingga mereka tidak dapat berusaha di muka bumi untuk mencukupi kehidupan mereka. Namun sifat 'iffah mereka menghalangi mereka untuk meminta secara terang-terangan kepada orang lain, sehingga orang yang tidak mengenal mereka tidak mengetahui keadaan mereka yang sebenarnya dan bahkan mereka dikira orang-orang yang berkecukupan. Karena itu, orang-orang yang mengetahui keadaan mereka yang sebenarnya, harus membantu mereka agar usaha mereka berjihad di jalan Allah dalam berbagai bentuknya tetap berjalan, sementara harga diri mereka sehingga mereka menahan diri untuk memintaminta juga tetap terjaga. 
ljtihad, Jurnal Wacana Hukum Islam dan Kemanusiaan, Volume 15, №. 1, Juni 2015: 137-158

Sekalipun ayat ini secara khusus berbicara tentang kelompok fakir dari kalangan muhajirin, tetapi pesan moralnya bersifat umum, yakni anjuran untuk berinfak kepada orang-orang fakir yang mengabdikan dirinya di jalan jihad dan memerlukan bantuan ekonomi, tetapi kondisi mereka menghalangi mereka untuk mencari kehidupan (berusaha), dan di sisi lain sifat harga diri mereka ('iffah) menghalangi mereka untuk meminta bantuan secara terangterangan kepada orang lain (Qumb, 1412:1/315).

Ada lima sifat fakir yang disebutkan dalam ayat ini. Pertama, al-ihsär $\bar{f}$ sabilillăh. Maksudnya, mereka yang membatasi dirinya untuk berjihad atau melakukan perbuatan yang diridhai Allah, karena jika mereka sibuk mencari kehidupan kepentingan umat yang menjadi pekerjaan mereka akan terabaikan. Karena itu kehidupan mereka dijamin oleh Baitul Mal. Kedua, mereka tidak memiliki kesanggupan untuk bekerja atau berusaha di bumi, seperti berbisnis dan sebagainya karena sakit atau takut menghadapi musuh. Ketiga, mereka menjaga kehormatan dirinya (al-ta'affuf) dan berusaha mensucikan dirinya dari keinginan terhadap milik orang lain, sehingga orang yang tidak tahu tentang kondisi mereka yang sebenarnya mengira mereka sebagai orang kaya. Keempat, mereka memiliki ciri-ciri khusus yang hanya diketahui oleh ketajaman hati orang Mukmin yang mencari orang yang pantas diberi, karena orang yang membutuhkan tidak akan sulit dikenal bagi orang orang yang tajam pandangannya sekalipun dia berusaha untuk menutupinya. Kelima, mereka tidak meminta-minta kepada orang lain secara paksa. Atau maknanya adalah mereka tidak meminta kepada orang lain, baik secara paksa (kasar) atau secara lembut dan belas kasihan (al-Maragy, 1946:3/49-50)

QS. al-Tawbah [9]:60:

"Sesungguhnya zakat-zakat itu, hanyalah untuk orang-orang fakir, orang-orang miskin, amilin (para petugas zakat), muallaf (orang yang dibujuk) hatinya, riqab (untuk memerdekakan budak), garimin (orang-orang yang berhutang), sabilillah dan ibnu sabil, sebagai sesuatu ketetapan yang diwajibkan Allah; dan Allah Maha Mengetahui lagi Maha Bijaksana." (QS. al-Tawbah [9]:60).

Ayat ini menyebutkan bahwa di antara kelompok yang berhak menerima zakat adalah orang fakir (fuqarā). Dalam ayat sebelumnya (ayat 58 dan 59) digambarkan bahwa ada yang keberatan dengan pembagian Nabi Saw dan mereka menuduh bahwa beliau tidak adil karena membagikan kepada para penggembala dan lain-lain. Ayat ini membenarkan sikap 
Nabi tersebut, sambil menjelaskan bahwa sedekah (zakat) bukan untuk mereka yang mencemooh itu, tetapi untuk orang-orang fakir, miskin dan yang lainnya. Jadi, ayat ini merupakan dasar pokok tentang kelompok-kelompok yang berhak menerima zakat (Shihab, 2002:595-596).

QS. al-Hajj [22]:28:

"Supaya mereka menyaksikan berbagai manfaat bagi mereka dan supaya mereka menyebut nama Allah pada hari yang telah ditentukan atas rezeki yang Allah telah berikan kepada mereka berupa binatang ternak. Maka makanlah sebagian daripadanya dan (sebagian lagi) berikanlah untuk dimakan orang-orang yang sengsara lagi fakir"' (QS. al-Hajj [22]:28).

Ayat ini berada dalam rangkaian ayat-ayat tentang haji dan syiar-syiarnya. Di antara syiar haji adalah menyembelih hewan kurban, dan ayat ini memerintahkan agar daging kurban itu diberikan kepada orang yang sengsara (al-bäis) dan orang fakir, disamping orang yang berkurban pun boleh memakannya (Qutb, 1412:4/2420).

QS. al-Hasyr [59]:8:

"(Juga) bagi orang-orang fakir yang berhijrah yang diusir dari kampung halaman dan dari harta benda mereka (karena) mencari karunia dari Allah dan keridhaan (Nya) dan mereka menolong Allah dan Rasul-Nya. Mereka itulah orang-orang yang benar.” (QS. al-Hasyr [59]:8).

Ayat ini menyebutkan bahwa diantara kelompok yang berhak atas fa'i adalah orang fakir. Fa' $i$ adalah semua harta yang dikuasai kaum Muslim dari harta orang kafir tanpa pengerahan pasukan berkuda maupun unta, atau ditaklukkan tanpa kesulitan dan peperangan. Fa' $i$ berbeda dengan ganimah, karena ganimah diperoleh oleh kaum Muslim dengan usaha, mengerahkan kuda dan unta. Dengan kata lain, diperoleh melalui peperangan (al-Qurmubij: 1964, 8/1). Contoh harta fa'i adalah harta yang diperoleh kaum Muslim dari Yahudi Bani Nadir; kampung halaman dan harta-harta yang ditinggalkan oleh kaum kafir karena gentar menghadapi kaum Muslim. Kaum Muslim berhak menguasai semua harta benda yang ditinggalkan kaum kafir. Harta fa'i juga mencakup harta-benda yang diserahkan kaum kafir karena takut menghadapi tentara Islam.

Sekalipun kaum fakir yang dibicarakan dalam ayat ini adalah kaum fakir muhajirin, sebagaimana ayat sebelumnya, namun makna dari ayat ini lebih luas dan bersifat umum. 
ljtihad, Jurnal Wacana Hukum Islam dan Kemanusiaan, Volume 15, No. 1, Juni 2015: 137-158

Yakni kewajiban membebaskan dan memberdayakan kaum fakir, terutama mereka yang terusir dari kampung halamannya dan dari harta milik yang menjadi sandaran dan tumpuan kehidupan mereka.

\section{Makna term miskin dalam al-Qur'an}

Kata "miskin" dalam Kamus Besar Bahasa Indonesia, diartikan sebagai tidak berharta benda; serba kekurangan (berpenghasilan sangat rendah) (Pusat Bahasa, 2008:961). Dari bahasa aslinya, Arab, kata miskin terambil dari kata sakana, yang akar hurufnya terdiri dari sin-käfnūn, yang berarti "diam, tenang, tidak bergerak" (lawan dari goncangan dan gerakan) (alRazy, 1979: 3/388). Al-Ragib al-Isfahany mendefinisikan miskin sebagai seorang yang tidak memiliki sesuatu pun. Karena makna miskin lebih rendah daripada makna fakir (al-Isfahany, t.th.:243). Dalam kamus al-Mubịt, miskin diartikan "orang yang tidak memiliki sesuatu, atau orang yang memiliki sesuatu tetapi tidak mencukupinya, atau orang yang tidak dapat bergerak (diam) karena kefakiran". Bisa juga berarti orang yang hina dan lemah (Abady, 1999:1087).

Makna kebahasaan ini mengisyaratkan bahwa istilah miskin menggambarkan akibat dari keadaan diri seseorang atau sekelompok orang yang lemah. Ketika seseorang itu tidak berhasil mengembangkan potensi dirinya secara optimal, yakni potensi kecerdasan, mental dan keterampilan; maka keadaan itu akan berakibat langsung pada kemiskinan, yakni ketidakmampuan mendapatkan, memiliki, dan mengakses sumber-sumber rezeki sehingga ia tidak memiliki sesuatu apa pun untuk memenuhi kebutuhan hidupnya. Orang miskin itu memiliki tenaga untuk bekerja, tetapi ia tidak melatih dan membiasakan dirinya untuk menjadi pekerja yang terampil. Orang miskin itu juga memiliki potensi untuk mengembangkan dirinya memiliki keahlian tertentu, tetapi ia tidak berhasil mengembangkan dirinya menjadi pekerja yang ulet. Ia memilih pola hidup sakana; diam, jumud, statis, tidak mengembangkan skill atau keterampilan dan keahlian dalam hidupnya karena malas. Akibatnya ia miskin, tidak memiliki sesuatu apa pun untuk memenuhi kebutuhan hidupnya. Al-Qur'an pun memandang bahwa kemiskinan itu merupakan al-maskanah (kehinaan), karena manusia yang seharusnya bertanggungjawab terhadap dirinya sendiri menjadi beban orang lain, semata-mata karena mentalitasnya yang malas (Ismail, 2012:39) 
Dalam al-Qur'an, kata sakana dan derivasinya terulang sebanyak 69 kali. Tetapi tidak semuanya berhubungan dengan orang miskin. Ayat-ayat al-Qur'an yang bermakna orang miskin terdapat dalam 23 ayat dalam 16 surat (7 surat makiyyah dan 9 surat madaniyyah) dengan bentuk-bentuk sebagai berikut:

Pertama, dalam bentuk tunggal, yaitu miskin (terdapat dalam QS. al-Baqarah [2]:184 dan al-Qalam [68]:24), miskīnan (QS. al-Mujādilah [58]:4; al-Insān [76]:8; al-Balad [90]:16), almiskin (QS. al-Isrā' [17]:26; al-Rūm [30]:38; al-Hāaqah [69]:34; al-Muddaththir [74]:44; alFajr [89]:18; al-Māūù [107]:3).

Kedua, dalam bentuk plural, yaitu masäkin (QS. al-Mäidah [5]:89, 95; al-Kahf [18]:79), al-masākīin (QS. al-Baqarah [2]:83, 177, 215; al-Nisā' [4]:8, 36; al-Anfäl [8]:41; al-Tawbah [9]:60; al-Nūr [24]:22, dan al-Hasyr [59]:7).

Dari 23 ayat di atas, ayat-ayat yang menyebut orang miskin sebagai pihak yang harus dibantu kehidupan ekonominya sebanyak 21 ayat, yaitu QS. al-Baqarah [2]:83, 177, 215, alNisā' [4]:8, 36, al-Mā'idah [5]:89, 95, al-Anfäl [8]:41, al-Tawbah [9]:60, al-Isrā' [17]:26, alNūr [24]:22, al-Rūm [30]:38, al-Mujādilah [58]:4, al-Hasyr [59]:7, al-Muddaththir [74]:44, alInsān [76]:8, al-Fajr [89]:18, al-Balad [90]:16, dan al-Mà'ūn [107]:3.

Dari ayat-ayat tersebut, setidaknya ada dua kesimpulan yang dapat diambil: Pertama, orang miskin sebagai objek yang diberi atau yang berhak menerima bantuan, seperti perbuatan baik [ihsāan] (QS. al-Baqarah [2]:83 dan al-Nisā' [4]:36), bantuan harta secara umum (QS. alBaqarah [2]:177), makanan (QS. al-Hāqqah [69]:34, al-Muddaththir [74]:44, al-Insān [76]:8, al-Fajr [89]:18, al-Balad [90]:16, dan al-Mà'ün [107]:3), zakat (QS. al-Tawbah [9]:60), fidyah berupa makanan/bahan makanan (QS. al-Baqarah [2]:184), sebagian dari harta warisan sebelum dibagikan kepada ahli waris (QS. al-Nisa' [4]:8), makanan atau pakaian sebagai bentuk kafarah pelanggaran sumpah (QS. al-Mä'idah [5]:89), makanan yang diberikan karena pelanggaran dalam haji (QS. al-Mà'idah [5]:95), makanan sebagai kafarah dhihar (QS. alMujāilah [58]:4), ganimah (QS. al-Anfal [8]:41), fa’i (QS. al-Hasyr [59]:7), bantuan harta (QS. al-Isrā' [17]:26 dan al-Rūm [30]:38), bantuan (harta) dari orang-orang yang mempunyai kelebihan dan kelapangan (QS. al-Nür [24]:22). Ini menegaskan bahwa sebenarnya orang miskin memiliki banyak sumber bantuan agar mereka terbebas dari kemiskinannya, seandainya hak-hak itu diberikan kepada mereka. Di sisi lain, ini juga menunjukkan upaya al-Qur'an 
ljtihad, Jurnal Wacana Hukum Islam dan Kemanusiaan, Volume 15, No. 1, Juni 2015: 137-158

yang sangat serius dalam pemberdayaan dan pembebasan kaum miskin.

Kedua, sebagian dari ayat-ayat tersebut menghubungkan pemberian harta kepada orang miskin (baik yang sifatnya wajib atau anjuran) dengan kewajiban mengabdi (ibadah) kepada Allah dan larangan menyekutukannya (QS. al-Baqarah [2]:83, al-Nisā' [4]:36), keimanan kepada Allah, hari akhir, malaikat, kitab dan para Nabi (QS. al-Baqarah [2]:177, al-Haqqah [69]34, al-Insân [76]:8), jalan yang terjal dan mendaki (perjuangan yang berat) (QS. al-Balad [90]:16), shalat (QS. alMuddaththir [74]:44), puasa Ramadan (QS. al-Baqarah [2]:184), pelanggaran sumpah (QS. alMāidah [5]:89), pelanggaran atas larangan haji (QS. al-Măidah [5]:95), pelanggaran qiihar(QS. alMujāillah [58]:4), dan kedustaan terhadap agama (QS. al-Māun [107]:3).

Hal ini menegaskan bahwa keimanan dan ketaatan dalam ibadah formal (seperti shalat, puasa dan haji) harus melahirkan kesalehan sosial berupa kepeduliaan dan kepekaan terhadap nasib orang miskin. Disamping itu, hal ini menjelaskan bahwa keberpihakan Islam kepada fakir dan miskin (kaum dhu'afa) ini bukan hanya sebatas memecahkan persoalan sosial dan kemanusian mereka, tetapi lebih dari itu adalah bagaimana menyelamatkan mereka dari bahaya kesesatan dan kekafiran, kemudian membawa mereka menuju keselamatan dan kebahagiaan di akhirat. Inilah yang membedakan konsep al-Qur'an (Islam) dengan konsep konsep sekuler atau sosialis yang keberpihakan mereka kepada kaum dhu'afa hanya sebatas pada penyelesaian masalah sosial yang bersifat duniawi dan berjangka pendek.

Al-Qur'an juga menyebutkan dua kategori orang miskin sekaligus sikap mereka dalam menghadapi kemiskinan. Pertama, orang miskin yang tidak tahan menghadapi kemiskinannya, lalu mereka meminta hak mereka kepada orang kaya. Kedua, orang miskin yang memiliki kesabaran dan daya tahan luar biasa dalam menghadapi kemiskinannya. Mereka menahan diri untuk meminta hak mereka dikarenakan sikap mereka yang menjaga kehormatan dirinya $\left(t a^{\prime} a f f u f\right)$. Kedua kelompok inilah yang dijelaskan dalam ayat berikut:

"Dan pada harta-harta mereka terdapat hak untuk orang miskin yang meminta dan orang miskin yang tidak meminta" (QS. Al-Dhāriyāt [51]:19).

"Dan orang-orang yang dalam harta mereka terdapat hak tertentu untuk orang miskin yang meminta dan orang miskin yang tidak meminta” (QS. al-Ma`ărij [70]:24-25).

Tentang QS. al-Dhāriyāt [51]:19, Ibn Kaaìr menjelaskan bahwa "pada harta kaum beriman ada hak, yakni bagian tertentu yang diperuntukkan, bagi al-să’il dan al-maḥrüm. Adapun al- 
să'ilsudah umum dikenal, yakni orang miskin yang mulai mengambil prakarsa untuk meminta (haknya pada orang lain). Dan dia punya hak sebagaimana pendapat Imam Ahmad. Dari al-Husain bin Ali bahwa Rasulullah Saw bersabda, "Orang miskin yang meminta mempunyai hak walaupun dia datang dengan menunggang kuda" (HR. Abu Dawud) (Ibn Kaaiir, 1419:7/ 390). Sedangkan al-maḥrüm menurut Qatadah dan al-Zuhry adalah orang miskin yang tidak meminta sesuatu. Al-Zuhry mendasarkan pendapatnya pada hadis Rasulullah saw. (Ibn Kathir, 1419:7/391):

"Dari Abu Hurairah bahwa Rasulullah Saw bersabda: Orang miskin itu bukan orang yang berkeliling (mengemis) kepada manusia dan diberikan kepadanya sesuap atau dua suap, satu atau dua biji kurma, tetapi orang miskin itu adalah orang yang tidak memiliki kekayaan yang mencukupinya lalu dia diberi sedekah dan ia tidak meminta-minta kepada manusia" (HR. al-Bukhary)

“Abdullah (bin Mas'ud) berkata, bahwa Rasulullah Saw bersabda: Orang miskin itu bukan orang yang berkeliling (mengemis kepada manusia) dan buka orang yang diberikan kepadanya satu atau dua biji kurma, sesuap atau dua suap, tetapi orang miskin itu ialah orang menjaga kehormatan dirinya, yang tidak meminta kepada orang-orang sedikit pun, maka dia diberi sedekah.” (HR. Ahmad).

Memperhatikan makna dasar kata miskin sebagaimana dijelaskan di atas, diperoleh kesan bahwa faktor utama penyebab kemiskinan adalah sikap berdiam diri, enggan, atau tidak dapat bergerak dan berusaha. Keengganan berusaha adalah penganiayaan terhadap diri sendiri, sedang ketidakmampuan berusaha antara lain disebabkan oleh penganiayaan manusia lain. Yang pertama sering disebut "kemiskinan natural" dan yang kedua adalah "kemiskinan struktural".

Kemiskinan natural adalah kemiskinan alami atau keadaan miskin karena dari awalnya memang miskin. Kelompok masyarakat tersebut menjadi miskin karena tidak memiliki sumber daya yang memadai baik sumber daya alam, sumber daya manusia maupun sumber daya pembangunan, atau kalaupun mereka ikut serta dalam pembangunan, mereka hanya mendapat imbalan pendapatan yang rendah. Menurut Baswir, kemiskinan natural adalah kemiskinan yang disebabkan oleh faktor-faktor alamiah seperti karena cacat, sakit, usia lanjut atau karena bencana alam (Baswir, 1997:23). Kondisi kemiskinan seperti ini menurut Kartasasmita disebut sebagai persisten poverty, yaitu kemiskinan yang telah kronis atau turun temurun. Kemiskinan ini biasaya terjadi di daerah yang pada umumnya kritis sumberdaya 
ljtihad, Jurnal Wacana Hukum Islam dan Kemanusiaan, Volume 15, No. 1, Juni 2015: 137-158

alamnya atau daerah yang terisolir (Kartasasmita, 1996:235),

Kemiskinan struktural adalah kemiskinan yang disebabkan oleh faktor-faktor buatan manusia seperti kebijakan ekonomi yang tidak adil, distribusi aset produksi yang tidak merata, korupsi dan kolusi serta tatanan ekonomi dunia yang cenderung menguntungkan kelompok masyarakat tertentu. Menurut Sumodiningrat, kemiskinan struktural muncul disebabkan karena berupaya menanggulangi kemiskinan natural, yaitu dengan direncanakan bermacam-macam program dan kebijakan. Namun karena pelaksanaannya tidak seimbang, pemilikan sumber daya tidak merata, kesempatan yang tidak sama menyebabkan keikutsertaan masyarakat menjadi tidak merata pula, sehingga menimbulkan struktur masyarakat yang timpang (Sumodiningrat, 1998:67).

Sementara menurut Kartasasmita, hal ini disebut accidentalpoverty, yaitu kemiskinan karena dampak dari suatu kebijaksanaan tertentu yang menyebabkan menurunnya tingkat kesejahteraan masyarakat (Kartasasmita, 1996:235). Atau kemiskinan yang diderita oleh suatu golongan masyarakat karena struktur sosial masyarakat tersebut tidak dapat ikut menggunakan sumber-sumber pendapatan yang sebenarnya tersedia. Kesan ini lebih jelas lagi bila diperhatikan bahwa jaminan rezeki yang dijanjikan Allah swt., ditujukan kepada makhluk yang dinamainya dābbah, yang arti harfiahnya adalah yang bergerak.

"Dan tidak ada suatu binatang melata pun di bumi melainkan Allah lah yang memberi rezekinya, dan Dia mengetahui tempat berdiam binatang itu dan tempat penyimpanannya. Semuanya tertulis dalam kitab yang nyata (Lawh Maḥudh). Dan tidak ada suatu binatang melatapun di bumi melainkan Allah-lah yang memberi rezkinya, dan Dia mengetahui tempat berdiam binatang itu dan tempat penyimpanannya. Semuanya tertulis dalam kitab yang nyata (Lauh Mạ̣füdh) (QS. Hūd [11]:6).

Ayat ini "menjamin” siapa yang aktif bergerak mencari rezeki, bukan yang diam menanti. Lebih tegas lagi dinyatakannya bahwa:

"Dan Dia telah memberikan kepadamu (keperluanmu) dari segala apa yang kalian mohonkan kepadanya. Dan jika kalian menghitung nikmat Allah, kalian tidak dapat kamu menghinggakannya. Sesungguhnya manusia it sangat zalim dan sangat ingkar (atas nikmat Allah)" (QS. Ibrāhim [14]: 34).

Pernyataan al-Qur'an di atas dikemukakan setelah menyebutkan aneka nikmat Allah, seperti langit, bumi, hujan, laut, bulan, matahari, dan sebagainya. Sumber daya alam yang 
disiapkan Allah untuk umat manusia tidak terhingga dan tidak terbatas. Seandainya sesuatu telah habis, maka ada alternatif lain yang disediakan Allah selama manusia berusaha. Oleh karena itu, tidak ada alasan untuk berkata bahwa sumber daya alam terbatas, tetapi sikap manusia terhadap pihak lain, dan sikapnya terhadap dirinya itulah yang menjadikan sebagian manusia tidak memperoleh sumber daya alam tersebut.

Kemiskinan juga terjadi akibat adanya ketidakseimbangan dalam perolehan atau penggunaan sumber daya alam itu, yang diistilahkan oleh ayat di atas dengan sikap aniaya (zalim), atau karena keengganan manusia menggali sumber daya alam itu atau untuk menemukan alternatif pengganti, yang oleh ayat itu disebut sikap ingkar (kufur).

Sementara, Asep Usman Ismail menyebutkan empat faktor yang menyebabkan kemiskinan dilihat dari sisi mentalitas (Ismail, 2012:9-10): Pertama, al-da î f, yakni keadaan diri seseorang yang diliputi kelemahan, yakni lemah semangat, lemah akal dan ilmu, lemah fisik, dan lemah keterampilan sehingga tidak sanggup menjalankan fungsinya sebagai pemimpin atau khalifah Allah di muka bumi. Kedua, al-khawf, yakni keadaan diri seseorang yang diselimuti oleh suasana takut yang mencekam sehingga tidak memiliki keberanian untuk mencoba bekerja, berusaha, berdagang, atau menjadi tukang, karena tidak berani mengambil resiko gagal, rugi atau kehilangan modal. Ketiga, al-kaslān, yakni keadaan jiwa seseorang yang diliputi oleh kemalasan sehingga kehilangan kesempatan, waktu, dan peluang untuk mengembangkan potensi dirinya dengan optimal. Sebenarnya setiap orang memiliki potensi untuk menjadi orang berhasil dalam memenuhi kebutuhan dasarnya, tetapi seorang pemalas menjadi fakir dan miskin karena kemalasannya. Keempat, al-bakhil, yakni keadaan diri seseorang yang didominasi oleh sifat kikir. Sifat dan karakteristik kebakhilan ini menjadikan diri seseorang hanya bisa menerima, tetapi tidak bisa menyalurkan sehingga dirinya seperti saluran air yang tersumbat. Akibatnya tidak ada air yang mengalir ke dalam pipa yang tersumbat; dan lama kelamaan kadar air dalam pipa tersumbat itu berkurang, bahkan hingga tidak ada sama sekali.

Mencermati beberapa pendapat di atas, tampak bahwa kemiskinan disebabkan oleh banyak faktor -salah satunya adalah faktor mentalitas- sehingga kemiskinan menjadi persoalan yang cukup kompleks. Karena itu mengatasinya pun sangat berat. Al-Qur'an menggambarkan perjuangan mengatasi kemiskinan dan memberdayakan kaum miskin sebagai " jalan terjal 
ljtihad, Jurnal Wacana Hukum Islam dan Kemanusiaan, Volume 15, №. 1, Juni 2015: 137-158

dan mendaki” (al- aqabah). Artinya sebuah perjuangan yang berat dan banyak tantangannya.

"Maka tidakkah sebaiknya manusia menempuh jalan yang mendaki lagi sukar? Tahukah kamu apakah jalan yang mendaki lagi sukar itu? (yaitu) melepaskan perbudakan atau memberi makan pada hari kelaparan (kepada) anak yatim yang ada hubungan kerabat atau orang miskin yang berkalang tanah" (QS. al-Balad [90]:11-16).

Dalam ayat itu, digambarkan bahwa melepaskan/membebaskan perbudakan dan memberi makan pada saat kelaparan kepada anak yatim dan orang miskin, dianggap perbuatan yang sulit, karena kecenderungan manusia itu adalah kikir (QS. al-Ma’arij [70]:21). Apalagi, anak yatim dan orang miskin, ketika itu, sering mendapat tekanan dan kekerasan. Karena itulah, dalam banyak ayat al-Qur'an yang berpesan untuk berbuat baik kepada mereka.

Al-Qurtuby menjelaskan bahwa kalimat $d h \bar{a}$ matrabah adalah orang yang tidak memiliki sesuatu pun, sehingga seakan-akan karena kemiskinannya tubuhnya menempel dengan tanah (tidak terhalang oleh sesuatu pun seperti ranjang, kasur atau tikar), ia tidak memiliki tempat berlindung kecuali tanah. Menurut Ibn 'Abbas maksudnya adalah orang yang terbuang ke jalan karena ia tidak memiliki rumah. Mujahid berpendapat maksudnya adalah seseorang yang tidak memiliki pakaian atau lainnya untuk melindungi dirinya dari tanah (al-Qurtuby, 1964:70).

Menilik berbagai pandangan di atas, miskin dha matrabah dalam istilah sekarang dapat diartikan gelandangan. Mereka adalah orang yang sangat miskin sehingga tidak memiliki tempat tinggal untuk melindungi diri dari terpaan alam. Status sosial gelandangan lebih rendah daripada status sosial orang miskin. Secara definitif Peraturan Pemerintah Republik Indonesia Nomor 31 Tahun 1980 tentang Penanggulangan Gelandangan dan Pengemis, pasal 1 menjelaskan bahwa gelandangan adalah "orang-orang yang hidup dalam keadaan tidak sesuai dengan norma kehidupan yang layak dalam masyarakat setempat, serta tidak mempunyai tempat tinggal dan pekerjaan yang tetap di wilayah tertentu dan hidup mengembara di tempat umum."

Dari ayat-ayat yang berbicara tentang fakir dan miskin, al-Qur'an tidak secara definitif mengemukakan siapa yang disebut fakir dan siapa mereka yang miskin. Karena itulah kemudian para ulama berbeda pendapat dalam menetapkan tolok ukur kemiskinan dan kefakiran.

Menurut Shafi'iyyah dan Hanabilah, fakir adalah orang yang tidak memiliki sesuatu sama sekali, atau orang yang memiliki harta atau pendapatan yang sedikit yang tidak mencukupi 
kebutuhannya. Menurut Hanafiyah adalah orang yang memiliki harta yang berkembang di bawah nishab. Malikiyah mendefinisikannya dengan orang yang memiliki sesuatu yang tidak mencukupi kebutuhan setahunnya. Sedangkan miskin menurut Hanafiyyah dan Malikiyyah orang yang tidak memiliki sesuatu pun. Menurut Shafi'iyyah, orang yang memiliki harta atau pekerjaan tetapi tidak mencukupinya. Sebagian ulama berpendapat fakir dan miskin adalah sama (Wizārah al-Awqāf: 1427:32/199-200).

Syekh al-Nabhany mengategorikan yang punya harta (uang) tetapi tak mencukupi kebutuhan pembelanjaannya sebagai orang fakir. Sementara itu, orang miskin adalah orang yang tak punya harta (uang), sekaligus tak punya penghasilan (al-Nabhany, t.th.: 236). Sebagian ulama berpendapat bahwa keadaan fakir lebih buruk dari keadaan miskin. Orang miskin memiliki sesuatu tetapi tidak mencukupinya sementara orang fakir tidak memiliki apa-apa. Mereka berdalil dengan firman Allah swt.:

Adapun bahtera itu adalah kepunyaan orang-orang miskin yang bekerja di laut, dan aku bertujuan merusaknya, karena di hadapan mereka ada seorang raja yang merampas setiap bahtera" (QS. al-Kahf [18]:79).

Menurut mereka, ayat di atas menyebut mereka orang miskin padahal mereka mempunyai perahu (bahtera) sebagai sumber penghidupannya. Pendapat itu dikemukakan Imam Syafi'i dan jumhur ulama. Sedangkan Abu Hanifah dan Ahlul Bait berpendapat bahwa orang miskin lebih "fakir" dari orang fakir. Mereka berdalil dengan firman Allah swt.:

Atau orang miskin yang berkalang tanah (QS. al-Balad [90]:11-16).

Menurut Yusuf al-Qaradawy orang miskin adalah orang yang memerlukan pertolongan. Yang termasuk kepada kelompok miskin ini adalah orang yang punya rumah, punya keluarga yang tidak meminta-minta, atau tidak dapat bergerak, baik karena ketuaan maupun karena kelemahan. Atau yang sedikit hartanya tetapi banyak tanggungannya, atau hasil pekerjaannya tidak mencukupi kebutuhan pokoknya. Imam Hasan al-Basri ditanya tentang seseorang yang punya rumah dan pembantu, apakah dia itu berhak menerima zakat? Hasan menjawab, dia boleh mengambil zakat bila dia berkekurangan. Tak ada salahnya. Imam Ahmad ditanya tentang orang yang memiliki barang tak bergerak, atau barang dagangan seharga 10 ribu dirham, lebih banyak atau lebih sedikit dari itu, tetapi tidak mencukupi keperluannya. Imam 
ljtihad, Jurnal Wacana Hukum Islam dan Kemanusiaan, Volume 15, No. 1, Juni 2015: 137-158

Aḥmad berkata, "Ia boleh mengambil zakat." Jadi, miskin bukan saja orang yang tidak mempunya apa-apa, tetapi yang tidak mempunyai sesuatu yang mencukupinya (al-Qardawy, 1985:87-88).

Berdasarkan pandangan para umam mazhab figh, Ali Yafie menjelaskan bahwa orang miskin adalah orang yang memiliki harta atau memiliki pekerjaan atau memiliki keduanya, tetapi harta atau hasil dari pekerjaannya itu hanya mencukupi seperdua atau lebih dari kebutuhan pokoknya. Sementara itu, menurutnya, fakir adalah orang yang tidak memiliki harta benda atau tidak memiliki penghasilan tetap atau memiliki penghasilan,tetapi penghasilannya hanya mencukupi kurang dari seperdua dari kebutuhan pokoknya (Yafie, 1986:6). Sementara itu Masdar F. Mas'udi mengatakan bahwa miskin menunjuk pada orang yang secara ekonomi lebih beruntung daripada si fakir. Tetapi secara keseluruhan ia tergolong orang-orang yang masih tetap kerepotan dalam memenuhi kebutuhan hidup kesehariannya (Mas'udi, 2005:115).

Al-Qur'an dan hadis juga tidak menetapkan angka tertentu lagi pasti sebagai ukuran kemiskinan, sehingga yang dikemukakan di atas dapat saja berubah. Namun yang pasti, alQur'an menjadikan setiap orang yang memerlukan sesuatu sebagai fakir atau miskin yang harus dibantu. Dalam pandangan Islam, tidak dapat dibenarkan seseorang yang hidup di tengah masyarakat Islam, sekalipun abl al-dhimmah (warga negara non-Muslim), menderita lapar, tidak berpakaian, menggelandang (tidak bertempat tinggal) dan membujang.

Dalam literatur modern, masalah kemiskinan banyak dikaji oleh para ahli dari berbagai aspek dan dari berbagai disiplin ilmu dengan menggunakan bermacam-macam ukuran dan konsep. Para ekonom membahas kemiskinan dengan menggunakan istilah standar hidup, pendapatan, dan distribusi pendapatan. Para sosiolog mengkajinya dengan menggunakan istilah kelas, stratifikasi,dan marjinalitas. Sedangkan, para pemerhati masalah-masalah sosial lebih memperhatikan konsep tingkat hidup yakni melihat tingkat pendapatan, masalah pendidikan, kesehatan, perumahan, dan kondisi sosial masyarakat secara umum. Namun, sampai saat ini belum ada definisi yang baku tentang kemiskinan. Hal ini menunjukkan bahwa masalah kemiskinan itu sangat kompleks dan pemecahannya tidak mudah.

Sekalipun al-Qur'an tidak secara definitif menjelaskan kriteria dan perbedaan antara fakir dan miskin, namun berdasarkan telaah terhadap ayat-ayat al-Qur'an tentang fakir dan miskin sebagaimana dipaparkan di atas, tampak bahwa kata fakir mengandung makna 
penanggung jawab (tulang punggung) yang tidak mampu bekerja karena cacat dan tidak memiliki akses, sementara ia sangat membutuhkan dan kesulitan.

Dari ayat-ayat Al-Quran tentang fakir sebagaimana dijelaskankan di atas, terutama ayatayat yang menyebut faqiir dan fuqarā yang terkait dengan pemberian sedekah (atau zakat) dalam QS. al-Baqarah [2]:273, QS. al-Tawbah [9]:60, QS. al-Nūr [24]:32 dan QS. al-Hasyr [59]:8- dapat disimpulkan beberapa hal, yaitu: (1) fakir tidak bekerja dan tidak mampu memberikan nafkah, (2) fakir karena terhalang jihad, (3) fakir karena hijrah keluar dari negeri, (4) fakir tidak nampak miskin/susah (secara fisik), dan (5) fakir tidak meminta-minta (dengan berkeliling kepada manusia).

Setelah memperhatikan makna bahasa dan penggunaan kata fakir di dalam al-Quran, maka konsep fakir dapat didefinisikan sebagai orang-orang yang terhalang dari mencari nafkah karena sebab amal maupun udhur. Sebab amal adalah karena aktivitas keagamaan atau amal syar'i seperti dakwah, jihad dan ribam. Sedangkan sebab udhur dikarenakan takdir kauni yang menimpa seseorang seperti cacat, lumpuh dan tua. Sebab-sebab tersebut adalah 'illat bagi seseorang untuk disebut sebagai fakir yang berhak atas harta zakat.

Pendekatan definisi seperti ini dapat membedakan konsep fakir dan miskin yang hampir selalu didekati dengan perspektif ekonomi. Secara umum para ahli fikih mendefinisikan fakir sebagai orang yang tidak bekerja. Akan tetapi tampaknya belum ada yang merinci sebab tidak bekerja tersebut. Penjelasan sebab-sebab ( $a s b \bar{a} b)$ seseorang tidak bekerja menjadi penting dikarenakan bekerja adalah sebuah kewajiban. Sedangkan orang yang tidak bekerja tanpa sebab yang dapat diterima oleh syariat, menurut fukaha terhalang dari mendapatkan harta zakat.

Dari definisi di atas kita dapat melihat bahwa alasan ('illat) bagi kelompok fakir berasal dari kemuliaan dan ujian yang diberikan oleh Allah Swt sehingga mereka mendapatkan penghormatan dan kompensasi berupa harta zakat dan sumber-sumber yang lain untuk mencukupi kebutuhan diri dan orang-orang yang menjadi tanggungannya. Sebab kemuliaan berasal dari amalan syar'iyyah, sedangkan sebab ujian berasal dari udhur kauniyyah. Maka, konsep fakir berdasarkan 'illat-nya sebagai mustahik zakat khususnya berbeda dengan kelompok (așnāf) lainnya. 
ljtihad, Jurnal Wacana Hukum Islam dan Kemanusiaan, Volume 15, №. 1, Juni 2015: 137-158

Sedangkan term “miskin” secara bahasa berarti “diam, tenang, tidak bergerak". Makna kebahasaan ini mengisyaratkan bahwa istilah miskin menggambarkan akibat dari keadaan diri seseorang atau sekelompok orang yang lemah. Ketika seseorang itu tidak berhasil mengembangkan potensi dirinya secara optimal, yakni potensi kecerdasan, mental dan keterampilan; maka keadaan itu akan berakibat langsung pada kemiskinan, yakni ketidakmampuan mendapatkan, memiliki, dan mengakses sumber-sumber rezeki sehingga ia tidak memiliki sesuatu apa pun untuk memenuhi kebutuhan hidupnya. Orang miskin itu memiliki tenaga untuk bekerja, tetapi ia tidak melatih dan membiasakan dirinya untuk menjadi pekerja yang terampil. Orang miskin itu memiliki potensi untuk mengembangkan dirinya memiliki keahlian tertentu, tetapi ia tidak berhasil mengembangkan dirinya menjadi pekerja yang ulet. Ia memilih pola hidup sakana; diam, jumud, statis, tidak mengembangkan skill atau keterampilan dan keahlian dalam hidupnya karena malas. Akibatnya ia miskin, tidak memiliki sesuatu apa pun untuk memenuhi kebutuhan hidupnya. Al-Qur'an pun memandang bahwa kemiskinan itu merupakan al-maskanah (kehinaan), karena manusia yang seharusnya bertanggungjawab terhadap dirinya sendiri menjadi beban orang lain, semata-mata karena mentalitasnya yang malas.

Dari sini, penting bagi muzakki dan amil zakat untuk mengetahui 'illat tersebut agar penyaluran zakat dapat tepat sasaran dan sesuai dengan tujuan zakat sebagai bentuk pemberdayaan ekonomi. Pemahaman akan perbedaan kriteria kedua kelompok ini juga dapat digunakan dalam menilai bentuk zakat yang didistribusikan kepada mereka, apakah dalam bentuk bantuan tunai langsung yang bersifat komsumtif ataukah dana bergulir yang dapat memberikan lapangan pekerjaan kepada mereka.

\section{Penutup}

Berdasarkan pendekatan al-Qur'an tentang konsep fakir dan miskin, dapat disimpulkan bahwa term "fakir" secara bahasa mengandung makna penanggung jawab (tulang punggung) yang tidak mampu bekerja karena cacat dan tidak memiliki akses, sementara ia sangat membutuhkan dan kesulitan. Kata dapat didefinisikan sebagai orang yang terhalang dari mencari nafkah karena sebab amal maupun udhur. Sebab amal adalah karena aktivitas keagamaan atau amal syar'i yang mereka lakukan seperti kegiatan-kegiatan dakwah dan 
jihad. Sedangkan sebab udhur dikarenakan takdir kauni yang menimpa seseorang seperti cacat, lumpuh dan tua. Sebab-sebab tersebut menjadi illat bagi seseorang untuk disebut fakir yang berhak atas harta zakat dan pemberian-pemberian lainnya. Jadi, 'illat (alasan) bagi kelompok fakir berasal dari kemuliaan dan ujian yang diberikan oleh Allah Swt sehingga mereka mendapatkan penghormatan dan kompensasi berupa harta zakat dan yang lainnya untuk mencukupi kebutuhan diri dan tanggungannya. Sebab kemuliaan datang dari amalan syar'iyyah, sedangkan sebab ujian datang dari udhur kauniyyah.

Sedangkan term "miskin" secara bahasa berasal dari sakana; diam, tenang, dan tidak bergerak. Makna kebahasaan ini mengisyaratkan bahwa istilah miskin menggambarkan akibat dari keadaan diri seseorang yang lemah. Ketika seseorang itu tidak berhasil mengembangkan potensi dirinya secara optimal, baik potensi kecerdasan, mental dan keterampilan; maka keadaan itu akan berakibat langsung pada kemiskinan, yakni ketidakmampuan mendapatkan, memiliki, dan mengakses sumber-sumber rezeki sehingga ia tidak memiliki sesuatu apa pun untuk memenuhi kebutuhan hidupnya.

Orang miskin itu memiliki potensi untuk mengembangkan dirinya, tetapi ia tidak berhasil mengembangkan diri dan kemampuannya. Ia memilih pola hidup sakana; diam, jumud, statis, tidak mengembangkan skill atau keterampilan dalam hidupnya karena malas. Akibatnya ia miskin, tidak memiliki sesuatu apa pun untuk memenuhi kebutuhan hidupnya. Al-Qur'an pun memandang bahwa kemiskinan itu merupakan al-maskanah (kehinaan), karena manusia yang seharusnya bertanggungjawab terhadap dirinya sendiri menjadi beban orang lain, sematamata karena mentalitasnya yang malas.

\section{Daftar pustaka}

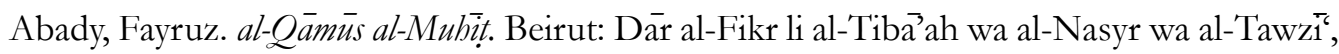
1999.

Baswir, Revrisond. Agenda Ekonomi Kerakyatan. Yogyakarta: Pustaka Pelajar, 1997.

CD Program al-Qur'an, Holy Quran, versi 6.50, Jeddah: Sakhr, 1997

CD Program Hadis, Mausū'at al-Hadis al-Syarif, edisi 6.2, Jeddah: Harf Information Technology Company, 1998-2000.

Hafidhuddin, Didin, dkk. Figh Zakat Indonesia. Jakarta: Badan Amil Zakat Nasional (BAZNAS), 2013. 
ljtihad, Jurnal Wacana Hukum Islam dan Kemanusiaan, Volume 15, No. 1, Juni 2015: 137-158

Ibn Kathir, Abu al-Fida' Isma'il bin Umar. Tafsir al-Qur'an al-Adhim. muhaqqiq Muhammad Husain Syams al-Din, Beirūt: Dār al-Kutub al-'Ilmiyyah, cet ke-1, 1419 H.

Isfahany al-, al-Ragib. Mufradàt $\bar{f}$ Garib al-Qur'ān. Beirūt: Dār al-Ma'rifah, t.th.

Ismail, Asep Usman. Al-Qur'an dan Kesejabteraan Sosial. Jakarta: Lentera Hati, 2012.

Kartasasmita, Ginanjar. Pembangunan untuk Rakyat (Memadukan Pertumbuhan dan Pemerataan). Jakarta: PT. Pustaka Cidesindo, 1996.

Majma' al-Lugah al-'Arabiyyah. al-Mu'jam al-Wasit. Kairo: Dār al-Da'wah, t.th.

Maragy al-, Ahmad bin Mustafa. Tafsir al-Maragy, Mesir: Syirkah Maktabah wa Mațba'ah Muștafā al-Bāby al-Halaby wa Aulāduhu, cet ke-1, 1946.

Mas'udi, Masdar F. Menggagas Ulang Zakat. Bandung: Mizan, 2005.

Nabhany al-, Syekh. Niz̧ām al-Iqtishäd fi al-Isläm, Beirut: Dār al-Ummah, t.th.

Peraturan Pemerintah Republik Indonesia Nomor 31 Tahun 1980 tentang Penanggulangan Gelandangan dan Pengemis.

Qaradawy al-, Yusuf. Fiqh al-Zakāh: Dirāasat Muqaranah li A ḥkamihā wa Falsafatihä fi Daw alQur'an wa al-Sunnah. Beirū: Mu'assasah al-Risāah, cet ke-2, 1973.

Qaradawy al-, Yusuf. Mushkilah al-Faqr wa Kayfa 'Alajabā al-Isläm. Beirut: Mu'assasah alRisalah, 1985.

Qurtuby al-, Abu Abdillah Muhammad bin Ahmad bin Abi Bakr bin Farh al-Ansari alKhazrajy Syams al-Din. al-Jami' li A hlkäm al-Qur'an. tahqiq Ahmad al-Barduny wa Ibrahim Atfisy, Kairo: Dār al-Kutub al-Mișriyyah, cet ke-2, 1964.

Qutb, Sayyid. Fī Zilāl al-Qur'ann. Kairo: Dār al-Syurūq, cet. ke-17, 1412.

Razy al-, Ahmad bin Faris bin Zakariya al-Qazwaini. Mujam Maqāyis al-Lugah. muhaqqiq 'Abd al-Salam Muhammad Harun, Beirūt: Dār al-Fikr, 1979.

Sabiq al-, Al-Sayyid. Fiqh al-Sunnah. Beirūt: Dār al-Kitāb al-Arabi, t.th.

Shihab, M. Quraish. Tafsir al-Misbab; Pesan, Kesan dan Keserasian Al-Qur'an. Jakarta: Penerbit Lentera Hati, cet. I, 2002.

Sumodiningrat, Gunawan. Poverty in Indonesia: Concept, Fact and Policy Alleviation, Paper Presented at Indonesia's New Order: Past, Present, Future, 4-8 Desember 1989, Canberra: The Australian national University, 1998.

Tim Penyusun Kamus Pusat Bahasa, Kamus Bahasa Indonesia, Jakarta: Pusat Bahasa Departemen Pendidikan Nasional, 2008.

Wizārah al-Awqāf wa al-Shu'ūn al-Islāmiyyah. al-Mawsü'ah al-Fiqhiyah al-Kuwaitiyyah. Kuwait: Dār al-Salāsil, 1427 H.

Yafie, Ali. Islam dan Problematika Kemiskinan. Jakarta: P3M, 1986. 